\title{
New biodegradable composites from starch and fibers of the babassu coconut
}

\author{
Carla Veronica Rodarte de Moura ${ }^{1^{*}}$ (D), Douglas da Cruz Sousa ${ }^{1}$ (D), Edmilson Miranda de Moura ${ }^{1}$ (D), \\ Eugênio Celso Emérito de Araújo² (D) and Ilza Maria Sittolin² (B) \\ 'Departamento de Química, Universidade Federal do Piauí - UFPI, Teresina, PI, Brasil \\ ${ }^{2}$ Empresa Brasileira de Pesquisa Agropecuária - EMBRAPA Meio-Norte, Teresina, PI, Brasil \\ *carla@ufpi.edu.br
}

\begin{abstract}
This work aimed to obtain thermoplastic starch composites (TPS) derived from starch and fibers of babassu coconut. The (TPS) was prepared with $40 \%$ plasticizer (glycerol). The fibers underwent chemical treatment of alkalinization and bleaching. SEM images and infrared spectra showed that wax, lignin, and hemicellulose were removed from the fiber surface. SEM images of TPS starch showed a smooth and uniform surface, whereas images of the TPSWF composite (washed fiber) showed voids between the fiber and the TPS. This phenomenon was not observed in the SEM images of the composites TPSAF (alkalized fiber) and TPSBF (bleached fiber). The tensile strength and elastic modulus of the composites were higher than the pure TPS matrix. Concerning elongation, composites underwent less elongation than TPS. The mechanical properties found for the TPSWF and TPSAF composites do not differ. However, the mechanical properties of the TPSBF composite were better than the properties of the other composites.
\end{abstract}

Keywords: TPS, Babassu, composites, fiber, starch.

How cite: Moura, C. V. R., Sousa, D. C., Moura, E. M., Araújo, E. C. E., \& Sittolin, I. M. (2021). New biodegradable composites from starch and fibers of the babassu coconut. Polimeros: Ciência e Tecnologia, 31(1), e2021007. https:// doi.org/10.1590/0104-1428.09519

\section{Introduction}

Plastics are very versatile, malleable, lightweight, and low-cost polymeric materials that confer numerous advantages over other materials in several applications. However, due to environmental issues with the pollution caused by these materials, there is an urgent need to reduce long-lasting plastics, especially in disposable items, which have increased in recent years. This environmental issue has led to a global interest in replacing petroleum-derived polymers, which are not biodegradable, with biodegradable polymers derived from renewable sources ${ }^{[1,2]}$.

Among the various possibilities of using biodegradable materials, starch was widely used, as it is abundant in nature, and the cost is low. This biopolymer is produced by many plants and stored in the cells as an energy source. Also, agricultural products can be considered a way to reduce environmental pollution and consolidate such products for other purposes ${ }^{[3]}$. Starch is formed by glucose units, which occur naturally, have hydroxyl froups and are composed of partially crystalline microscopic granules. The polysaccharide chains that form the starch are interconnected through strong inter and intramolecular hydrogen bonds. These strong bonds hinder the movement of the polymer bonds resulting in low plasticity. A solution to improve the processability of starch is the addition of plasticizing agents such as glycerol sorbitol, xylitol, ethylene glycol, and water, heating and shear stress so that it becomes a workable plastic material, called thermoplastic starch (TPS) ${ }^{[4,5]}$. Among the plasticizers mentioned, glycerol is the classic plasticizer for starch because it forms compounds wich are colorless, transparent, odorless, and non-toxic properties ${ }^{[6]}$.

Thermoplastic starch (TPS) has properties that allow its processing using extrusion, injection, and compression molding ${ }^{[7]}$. However, TPS shows weak resistance to water absorption, i.e., it is hydrophilic and has low mechanical properties compared to conventional synthetic polymers, and these are limiting factors for its industrial application ${ }^{[8,9]}$. Some studies described in the literature show that TPS films need modifications to improve the mechanical properties and their low water absorption and, at the same time, not altering their biodegradability ${ }^{[10-12]}$. Different strategies to improve such weaknesses can be employed, for example, by mixing TPS with another polymeric material as well as by adding fillers ${ }^{[13,14]}$.

The literature shows that adding loads such as natural fibers, a more environmentally friendly material, would be a correct way to correct the minimize problems presented by TPS. However, it is necessary to promote the adhesion of the fiber to the TPS matrix. Authors have shown that if adhesion is not adequate, the mechanical properties tend to be reduced compared to the original product. Therefore, the challenge is to improve this adhesion and consequently obtain improvements in the generated composite properties ${ }^{[13,15]}$. 
Natural fibers have been used to reinforce polymer matrices to manufacture environmentally friendlily composites. These fibers have excellent mechanical performance, low density, and are easy to handle due to their non-abrasive nature. Also, they are renewable, biodegradable, and inexpensive ${ }^{[16-18]}$. Composites made with natural fiber and TPS are used for various industrial purposes, including automotive industry, civil construction, products for sports use, as surfboards and fishing rods ${ }^{[19,20]}$.

Natural fibers are mainly composed of lignin, hemicellulose, and cellulose. Such structures do not have good adhesion with the structure of the TPS and can affect the composites' process of preparation. Besides, natural fibers are hygroscopic and contain waxes in their composition that can hinder adhesion with TPS. Therefore, modifying the starch, using a plasticizer, and pre-treating the fibers with a chemical agent can result in composites with modified mechanical properties ${ }^{[21]}$. Several studies report the effects of lignocellulosic fibers on starch films from different sources, such as rice ${ }^{[22]}$, cassava ${ }^{[23]}$, peas ${ }^{[24]}$ and corn ${ }^{[25]}$.

Brazil has enormous potential for lignocellulosic fiber production, such as the Babassu (Orbignya speciosa) biomass. Babaçu is a palm tree found naturally in the North, Northeast, and Midwest regions of Brazil. The Babassu coconut has four parts: epicarp, mesocarp, endocarp, and almonds. Edible oil is extracted from the almonds. The other three components can be used to produce alcohol, fertilizer, charcoal, flour, and animal feed. The mesocarp is incorporated as a ground meal that serves as food for humans and animals ${ }^{[26]}$. Depending on the origin, between 60 and $70 \%$ of the flour is starch and is exploited to produce thermoplastic starch.

Therefore, this work aimed to improve thermoplastic starch's mechanical properties (TPS), reinforced with babassu coconut fibers. The effects of chemically treated fibers on the resulting composites, thermal, and spectroscopic properties were evaluated.

\section{Materials and Methods}

The Babassu starch (BS) and epicarp fibers were kindly provided by Embrapa Meio Norte (Piauí, Brazil). Glycerol and sodium hydroxide were purchased from Vetec. Sodium chloride was purchased from Sigma-Aldrich, and acetic acid was purchased from Synth. All reagents came with the analytical grade and were used without further purification.

\subsection{Processing of the Babassu Starch (BS) and Fibers}

$100 \mathrm{~g}$ of babassu starch (BS) was immersed in distilled water (1 L) and kept under mechanical stirring for $30 \mathrm{~min}$. This system then has settled overnight, and the supernatant was removed by siphoning. The BS obtained was dried in an oven for $12 \mathrm{~h}$ at $60^{\circ} \mathrm{C}$, ground, and sifted in a $53 \mu \mathrm{m}$ (270 mesh) sieve. The Babassu fibers were washed with tap water, ground in a knife mill, and dried in an oven at $90{ }^{\circ} \mathrm{C}$ for $12 \mathrm{~h}$. The dyed fibers were immersed in $\mathrm{NaOH}(4 \%)$ solution and mechanically stirred for two hours. Then, they have been dried in an oven for $12 \mathrm{~h}$ at $90{ }^{\circ} \mathrm{C}$. The washed fibers were immersed in a bleaching solution composed of equal parts of acetate buffer solution ( $2.7 \mathrm{~g}$ of sodium hydroxide and $7.5 \mathrm{ml}$ of glacial acetic acid in each $100 \mathrm{~mL}$ of solution) and aqueous sodium chloride solution ( $1.7 \%$ $\mathrm{w} / \mathrm{v})$. They were kept in this solution and mechanically agitated for four $\mathrm{h}$ at $70^{\circ} \mathrm{C}^{[14]}$. They have been then oven dried for $12 \mathrm{~h}$ at $90^{\circ} \mathrm{C}$.

The fibers thus obtained fibers were labelled, respectively, as washed fibers (WF), alkaline fibers (AF), and bleached fibers (BF).

\subsection{Synthesis of Thermoplastic Starch (TPS) and Composites}

$12.00 \mathrm{~g}$ of glycerol was dissolved in $50 \mathrm{~mL}$ of water and then $30.00 \mathrm{~g}$ of BS (corresponding to $60 \mathrm{BS}$ and $40 \%$ glycerol) were slowly added, and the system was placed under mechanical stirring for $5 \mathrm{~min}$. Stirring was sustained, and the mixture was heated to $100^{\circ} \mathrm{C}$ for $8 \mathrm{~min}$ to complete gelatinization. The gel formed was deposited on a glass plate, and the water evaporated in an oven at $60{ }^{\circ} \mathrm{C}^{[27]}$. The TPS was obtained (molded) by thermopressure, using a hydraulic press under a load of $3 \mathrm{t}$ at $130{ }^{\circ} \mathrm{C}$ for $30 \mathrm{~min}$. The composites have been obtained using $90 \%$ of TPS and $10 \%$ of fibers (washed, alkalized, or bleached). The quantity of TPS and fibers was mixed with $50 \mathrm{~mL}$ of water and placed under mechanical stirring for $5 \mathrm{~min}$, and then it was heated to $100{ }^{\circ} \mathrm{C}$ for $8 \mathrm{~min}$. The composites have been dried in an oven at $60{ }^{\circ} \mathrm{C}$ for 4 h. $^{[14]}$. The dried composites were wrought by thermopressure, using a hydraulic press under a load of $3 \mathrm{~T}$ at $130{ }^{\circ} \mathrm{C}$ for $30 \mathrm{~min}$.

The TPS and composites were designated as the following: Thermoplastic starch matrix (TPS), composites with washed fibers (TPSWF), composites with alkaline fibers (TPSAF), and composites with bleached fibers (TPSBF).

\subsection{Characterization}

Moisture and ash contents were analyzed by the methodology described by AOAC No 925.09 and AOAC No 923.03, respectively. The AOAC N ${ }^{\circ} 991.15$ methodology mesasures protein content; a nitrogen conversion factor of 5.75 was applied. The lipids measurements have been carried out following the procedure described by AOAC $\mathrm{N}^{0}$ 963.15. Food Fiber was measured by AOCS No 985.29. The amylose content was analyzed by the colorimetric iodine method, proposed by Perez and Juliano ${ }^{[28]}$. The TPS and the composites' moisture absorption tests were carried out following the guidelines of ASTM E104-02. Three specimens have been tested for each sample. The percentage of water absorbed was calculated using Equation: $W A \%=\left[M t-M_{0} / M_{0}\right] x 100$. $\mathrm{M}_{0}=$ initial mass of the test specimen, $\mathrm{Mt}=$ mass after a particular exposure time. Compression molded TPS and composites were laser cut as ASTM D638 type I samples. The tensile tests were performed on a Shimadzu AG-X 250 KN mechanical test machine following ASTM D638. FTIR analyzes were performed on a Perkin Elmer spectrometer, model Spectrum 100, the tablets being pressed in $\mathrm{KBr}$, and the spectra obtained with 32 scans in the range of 4000 to $400 \mathrm{~cm}^{-1}$. TG and DSC analyses were performed using a Shimadzu thermogravimetric analyzer, model TGA-60, and DSC-60. The samples were packed in Platinum samples, and the experiments have been carried out under nitrogen atmosphere, with a flow rate of $50 \mathrm{~mL} \mathrm{~min}^{-1}$. The temperature 
was raised to $600{ }^{\circ} \mathrm{C}(\mathrm{TG})$ and $500{ }^{\circ} \mathrm{C}(\mathrm{DSC})$, with a heating rate of $10{ }^{\circ} \mathrm{C} \mathrm{min}^{-1}$. X-ray diffraction analyzes were performed on a PANalytical Empyrean X-ray diffractometer, using $\mathrm{CoK} \alpha$ radiation with $40 \mathrm{kV} / 40 \mathrm{~mA}$. The scans were made in the range of $5^{\circ}-60^{\circ}$ at a speed of $2^{\circ} \mathrm{min}^{-1}$. A scanning electron microscope (FEI Quanta FEG 250) was used to obtain SEM images. The samples were placed on carbon tape and covered with a thin layer of gold in a Q150R ES quorum metallizer.

\subsection{Statistical analysis}

The chemical analysis of babassu starch and the composites' mechanical properties were analyzed using Analysis of Variance (ANOVA), using the STATISTICA ${ }^{\circledR}$ software (Version 10.0, StatSoft Inc., Tulsa, USA). All analyzes were performed in triplicate, and the results were expressed in terms of mean and standard deviation.

\section{Results and Discussions}

\subsection{Characterization of babassu starch and fibers}

The data from the centesimal analysis for BS are presented in Table 1. The chemical composition results found in our study were not different from those found in the literature. Except for humidity and purity, which Maniglia et al. ${ }^{[29]}$ found $(15.1 \%)$ and Ferreira et al. ${ }^{[30]}$ found $66.5 \%$, respectively. In our work, we found $6.35 \%$ humidity and $94 \%$ purity. This difference in humidity and purity may be due to drying or storing the material after processing.

The FTIR of BS (Figure 1A) presented bands attributed to $\mathrm{OH}$ groups at 3600 to $3100 \mathrm{~cm}^{-1}$. The $\mathrm{CH}_{2}$ and $\mathrm{CH}_{3}$ stretching bands appeared from 2910 to $2850 \mathrm{~cm}^{-1}$. At $1639 \mathrm{~cm}^{-1}$ corresponds to $\delta(\mathrm{O}-\mathrm{H})$ of the hydroxyl groups in the cellulose structure. The band in the $1245 \mathrm{~cm}^{-1}$ region is related to the $\mathrm{OH}$ group's flexural vibration of the glucose units. The bands range from 1161 to $1079 \mathrm{~cm}^{-1}$ have been attributed to $\alpha 1-4$ C-O-C linkage elongation, and 1026 and $1006 \mathrm{~cm}^{-1}$ have been attributed to $\mathrm{v}-\mathrm{C}-\mathrm{O}-\mathrm{H}$. For the fibers (Figure 1B), the most significant differences are at $1742 \mathrm{~cm}^{-1}, v(\mathrm{C}=\mathrm{O})$ for carboxylic esters, at $1650 \mathrm{~cm}^{-1}$, $v(\mathrm{C}-\mathrm{OH})$ for alcohol groups, and $1249 \mathrm{~cm}^{-1},(v-\mathrm{C}-\mathrm{O}-\mathrm{C})$ also due to the presence of lignin and hemicellulose ${ }^{[31-35]}$. Those band can be seen in the IR spectra of WF and AF fibers. The bands around $1464 \mathrm{~cm}^{-1}$ refer to $v(\mathrm{C}=\mathrm{C})$ of aromatic rings, aromatic vibrations, aromatic ring deformation, and -CHO out of plane vibrations. At 1172 and $895 \mathrm{~cm}^{-1}$, bands related to $\delta(\mathrm{C}-\mathrm{O}-\mathrm{C})$ of polysaccharides and $(\beta 1-4)$ linkage of glucose ring ${ }^{[35,36]}$. In $1042 \mathrm{~cm}^{-1}$, a band attributed to the $\mathrm{Si}-\mathrm{O}$ bond stretching was verified. The treatments applied to the fibers in this work were not enough to remove the fibers' silica. Campos et al. also observed this fact regarding composites made using palm oil mesocarp fibers and cassava starch $\operatorname{TPS}^{[37]}$.

The SEM images of BS, WF, AF, and BF are shown in Figure 2. The starch granules' morphology is related to their botanical origin and how they were isolated or processed. ${ }^{[38,13]}$

Table 1. Chemical Composition of Babassu Starch (BS).

\begin{tabular}{|c|c|c|c|}
\hline Parameter & $(\%)$ & Literature $^{[29]}$ & Literature $^{[30]}$ \\
\hline Moisture content* (g/100 g of total material) & $6.35 \pm 0.14$ & $15.1 \pm 1.6$ & $5.0 \pm 0.1$ \\
\hline Ash (g/100 g of dry material) & $0.31 \pm 0.01$ & $1.1 \pm 0.1$ & - \\
\hline Lipids (g/100 g of dry material) & $0.72 \pm 0.03$ & $1.8 \pm 0.4$ & $0.30 \pm 0.0$ \\
\hline Protein (g/100 g of dry material) & $1.02 \pm 0.06$ & $1.4 \pm 0.1$ & $1.2 \pm 0.1$ \\
\hline Food Fiber (g/100 g of dry material) & $4.25 \pm 0.27$ & $3.7 \pm 0.2$ & $8.6 \pm 0.1$ \\
\hline Amylose (g/100 g of starch) & $36.51 \pm 1.02$ & $36.6 \pm 0.5$ & - \\
\hline $\operatorname{Starch}(\mathrm{g} / 100 \mathrm{~g}$ of dry material) & $93.70 \pm 0.98$ & $92.0 \pm 0.4$ & $66.5 \pm 0.2$ \\
\hline
\end{tabular}

*Expressed on moisture basis, Starch (obtained by difference) $=100-($ Ash $(\%)+$ Lipids $(\%)+$ protein $(\%)+$ Food Fiber $(\%)$.
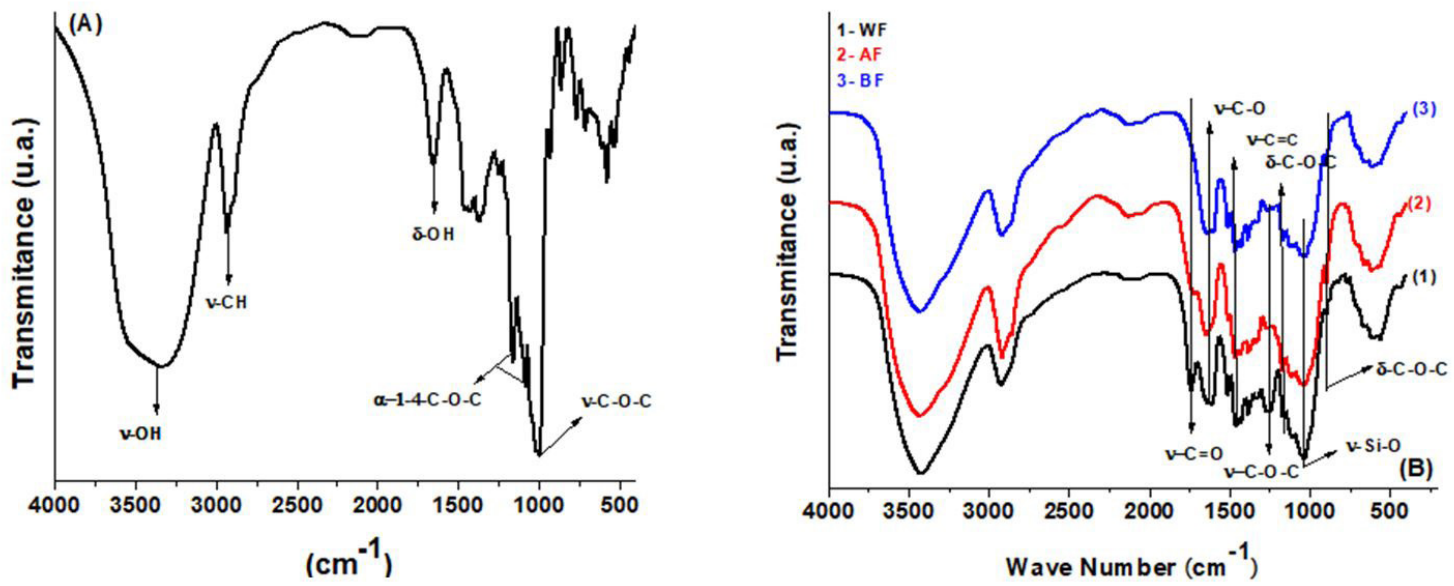

Figure 1. FTIR spectra of the BS (A), and WF, AF, and BF (B). 
The surface of the granules was predominantly smooth, without any grooves. Some granules' residues surface was noticed due to proteins, lipids, and fibers ${ }^{[39,40] \text {. }}$

The micrography of WF showed rough structures adhered to the surface, i.e., a layer formed by lignin, hemicellulose, and waxes ${ }^{[41]}$. Some untreated fibers may have holes, and these are filled with silica. Treatments can remove the silicon and leave the holes open ${ }^{[42]}$. Silica is present in longitudinal linear structures such as "tyloses," which can act as adhesion points between the resin and the matrix ${ }^{[43,44]}$. The FTIR spectra of fibers confirmed the presence of silica in WF fibers. The AF fibers presented a smoother surface than the WF fibers showing the interfibrillar structure. It was evidenced that the alkaline treatment removed part of the hemicellulose, lignin, and waxes ${ }^{[45,46]}$. The BF fibers showed more significant surface changes due to eliminating the residual lignin. Consequently, the fiber's internal structure was exposed, exhibiting a bundle of continuous oriented microfibrils ${ }^{[44]}$.

The micrography of WF showed rough structures. The diffractogram of BS (Figure 3 ) showed peaks at $2 \theta=5.91^{\circ}$, $11.45^{\circ}, 13.12^{\circ}, 17.52^{\circ}, 20.03^{\circ}, 23.33^{\circ}$, and $26.63^{\circ}$, typical of $\mathrm{A}$ and $\mathrm{B}$ type starches ${ }^{[47,48]}$. Then, it is classified as type C, with characteristics closer to type A starches ${ }^{[40,49]}$. The starch so-called starch $\mathrm{C}$ was described in leguminous seeds and banana ${ }^{[50]}$.

The crystallinity index (CI) found for the BS, WF, AF, and BF fibers are listed in Table 2. The crystallinity of BM $(27.65 \%)$ was lower than the one found by Maniglia et al. $(29.00 \%)^{[29]}$. Amylopectin has a branched structure and linear segments arranged in double helices stabilized by hydrogen bonds. This structure is associated with starch crystallinity. However, it is essential to note that the amount
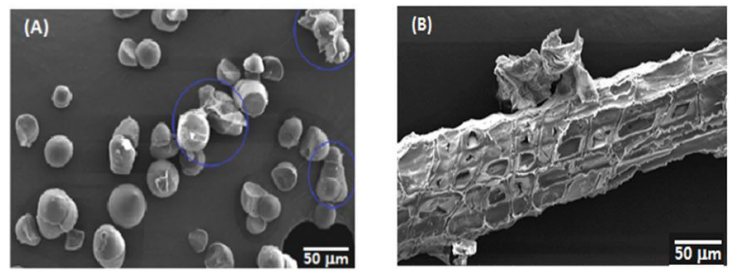

Figure 2. Micrography of (A) BS, (B) WF, (C) AF, (D) BF.

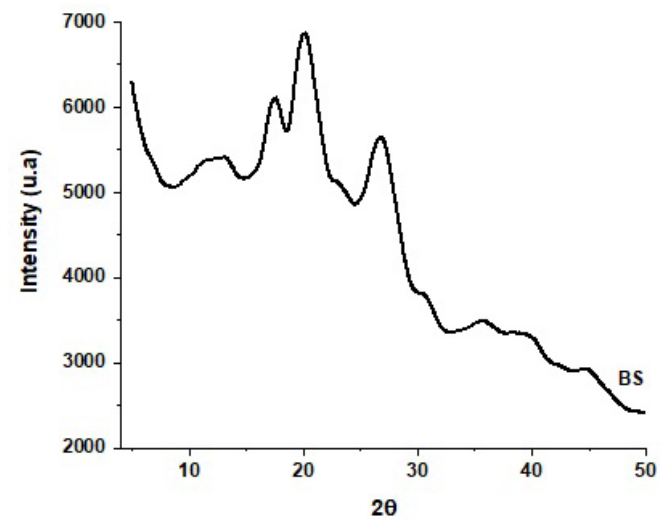

of amylose is high; the starch's crystallinity has decreased because amylose represents the starch's amorphous part. In our study, the amount of amylose $(36.45 \%)$ was higher than that found in the literature ${ }^{[29]}$; therefore, the crystallinity value was lower ${ }^{[50]}$.

The crystallinity of starch can also be influenced by other components present in starch, such as ash, protein, lipids, and crude fiber, or by the starch extraction method ${ }^{[51]}$. The epicarp fibers (Figure 3) exhibited similar diffraction patterns to those observed in other studies on Babassu epicarp fibers ${ }^{[31]}$, and fibers of other botanical origins. In the present work, the fiber diffraction profile was the same as cellulose type I, which is commonly found in lignocellulosic materials ${ }^{[52]}$.

Fibers (WF, AF, and BF) crystallinity increased progressively with the chemical treatments (Table 2). Furthermore, it is a consequence of the progressive removal of amorphous components (hemicellulose and lignin) promoted by the treatments, which allowed a higher ordering of the cellulose chains ${ }^{[53]}$. There is no difference between the crystallinity of TPS and TPSWF, TPSAF, and TPSBF composites. Although the results show a progressive increase when using fibers that have undergone chemical treatment, as seen in the fibers.

Table 2. Crystallinity Index.

\begin{tabular}{cl}
\hline Sample & CI\% \\
\hline BS & 27.65 \\
WF & 23.60 \\
AF & 41.81 \\
BF & 43.34 \\
TPS & 19.61 \\
TPSWF & 18.51 \\
TPSAF & 20.15 \\
TPSBF & 21.99 \\
\hline
\end{tabular}
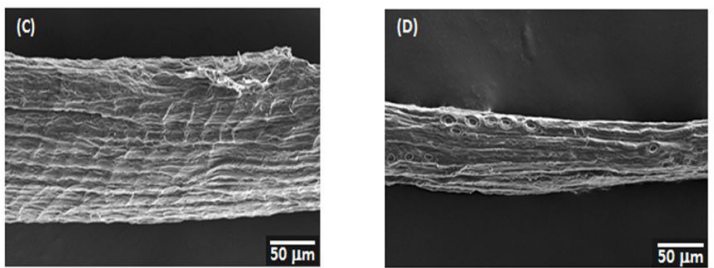

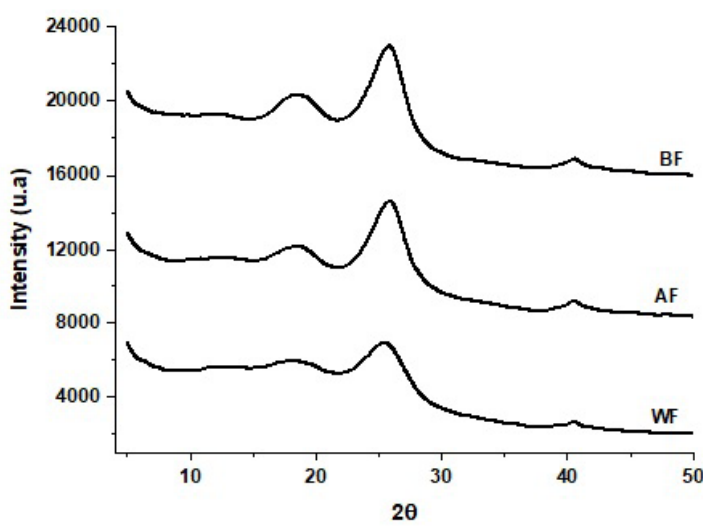

Figure 3. XRD of BS and Fibers. 
Figure 4 shows the TG/DTG and DSC curves of BS, $\mathrm{WF}, \mathrm{AF}$, and BF. Two events were observed in the TG/DTG curve of babassu starch (BS), and they were attributed to the removal of physically absorbed water $\left(67^{\circ} \mathrm{C}\right)$ and the degradation of hemicellulose $\left(359.5^{\circ} \mathrm{C}\right)^{[54,55]}$. BS has thermal stability up to $290^{\circ} \mathrm{C}$. On the other hand, the TG/DTG curve of the WF fiber presented three events, attributed to the removal of physically absorbed water $\left(49^{\circ} \mathrm{C}\right)$, degradation of hemicellulose $\left(300^{\circ} \mathrm{C}\right)$, and cellulose $\left(390^{\circ} \mathrm{C}\right)^{[54]}$.

TG/DTG curves of the alkaline fibers (AF) show a discrete event at $290^{\circ} \mathrm{C}$, attributed to the decomposition of lignin and hemicellulose. This event indicates that such compounds were not completely eliminated with the alkalinization treatment. Kabir et al. studied hemp fibers and found that treating the fibers with $4 \% \mathrm{NaOH}$ was insufficient to eliminate lignin and hemicellulose ${ }^{[42]}$. In this work, the same alkalinization treatment was carried out; i.e., the babassu fibers were treated with $4 \% \mathrm{NaOH}$ solution. TG/DTG curves of BF fibers, show just two events, one of them at $45{ }^{\circ} \mathrm{C}$ and other at $322.7^{\circ} \mathrm{C}$ related to water absorption and cellulose decomposition. In this case, the treatment was sufficinte to eliminate lignin and hemicellulose.

The DSC curves of all fibers show an endothermic event from $30^{\circ} \mathrm{C}$ to $150^{\circ} \mathrm{C}$, which corresponds to the loss of adsorbed water ${ }^{[37]}$. This event is more accentuated to washed fibers (WF), being the maximum at $80.2^{\circ} \mathrm{C}$. The event attributed to water absorption was observed at $96.2^{\circ} \mathrm{C}$ to alcanilized fibers (AF) and $70.6{ }^{\circ} \mathrm{C}$ to bleached fibers. An accentuated exotérmic event was seen at $420.5^{\circ} \mathrm{C}(\mathrm{WF})$, which correspond to hemicellulose and lignin decomposition ${ }^{[37,43]}$. The event was observed to alcanized fibers at $394.5^{\circ} \mathrm{C}$; however, it was less accentuated than washed fibers indicating that the hemicellulose and lignin were partially removed from the fibers. This result is following the SEM images, infrared and TG/DTG results. The event attributed to hemicellulose and lignina was not observed in DSC curve of the BF. All the fiber showed a peak at $474.3{ }^{\circ} \mathrm{C}(\mathrm{WF}), 445.3{ }^{\circ} \mathrm{C}(\mathrm{AF})$, and $420.4^{\circ} \mathrm{C}(\mathrm{BF})$ attributed to cellulose degradation, which is the predominant constituent of the fiber. Bhaduri et al. ${ }^{[56]}$ and Shafizadeh et al. ${ }^{[57]}$ observed that this endotherm is a consequence of dehydration and depolymerization of the cellulose component of the fiber, leading to the formation of flammable volatile products.

\subsection{Characterization of TPS and Composites}

SEM micrographs of TPS, TPSWF, TPSAF, and TPSBF are shown in Figure 5. TPS has a relatively smooth and even surface. No starch granules were observed, indicating that the method applied in TPS synthesis was suitable for restructuring of the granules ${ }^{[58,59]}$. SEM image of TPSWF clearly shows voids at the interface between the fiber and the thermoplastic matrix. The TPSAF and TPSBF composites' micrographs showed that the treatment applied to the fibers
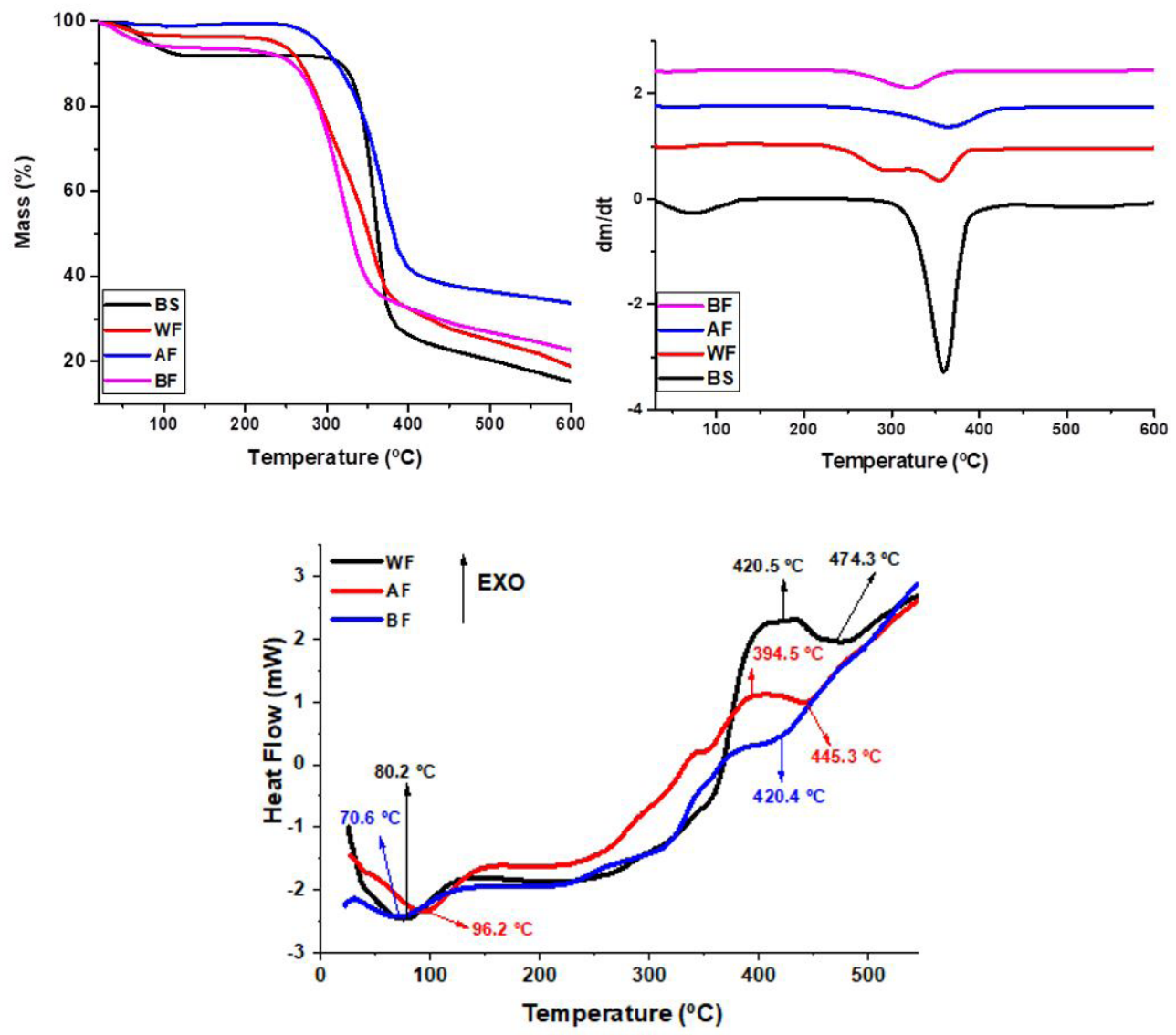

Figure 4. TG, DTG and DSC curves of WF, AF and BF. 


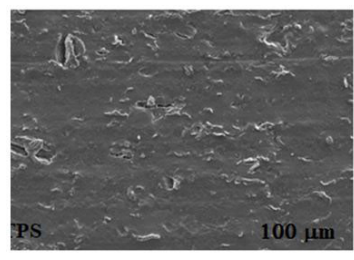

TPS

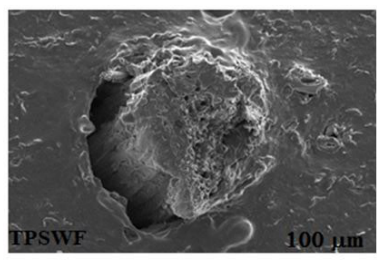

TPSWF

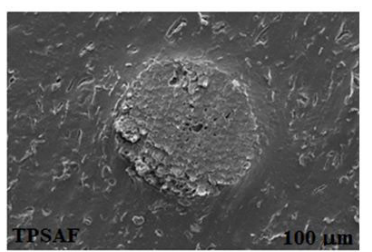

TPSAF

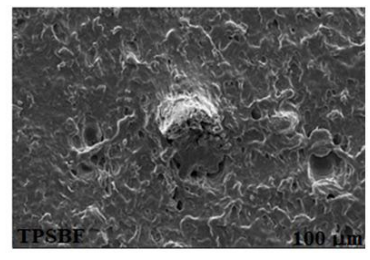

TPSBF

Figure 5. SEM Micrographs of the TPS, TPSWF, TPSAF, and TPSBF.

Table 3. Results of Mechanical Properties of Babassu TPS and Composites.

\begin{tabular}{lccccc}
\hline \multicolumn{1}{c}{ Starch type } & Plasticizer (\%) & $\begin{array}{c}\text { Tensile Strength } \\
\text { (MPa) }\end{array}$ & Elongation (\%) & $\begin{array}{c}\text { Elastic Modulus } \\
\text { (MPa) }\end{array}$ & Reference \\
\hline Cassava & Glycerol (40) & $2.2 \pm 0.1$ & $108.3 \pm 5.0$ & $174.6 \pm 1.8$ & 61 \\
Cassava & Glycerol (45) & $1.8 \pm 0.03$ & $50 \pm 4.2$ & $10.5 \pm 2.6$ & 23 \\
Babassu & Glycerol (19) & $63 \pm 4.1$ & $0.7 \pm 0,2$ & $4285 \pm 208$ & 26 \\
Kefiran & Glycerol (25) & $7.2 \pm 1.7$ & $135 \pm 1.4$ & $198 \pm 4.6$ & 67 \\
Raw oil palm & Glycerol (43) & $0.3 \pm 0.1$ & $79.0 \pm 27$ & $8.5 \pm 2$ & 37 \\
Horse chestnut & Glycerol (30) & $1.5 \pm 0.3$ & $1.02 \pm 0.04$ & $3.0 \pm 0.3$ & 40 \\
Corn & Glycerol (25) & $1.24 \pm 0.5$ & $48.7 \pm 0.01$ & $19.93 \pm 0.07$ & 63 \\
\hline \multicolumn{7}{c}{ Our Results } \\
\hline Babassu & Glycerol (40) & $31.67 \pm 1.07$ & $10.63 \pm 1.6$ & $120.65 \pm 2.55$ & $222.36 \pm 3.27$ \\
TPSWF & $45.38 \pm 1.15$ & $7.54 \pm 1.7$ & $231.65 \pm 3.19$ \\
TPSAF & $50.58 \pm 1.13$ & $6.87 \pm 1.5$ & $254.81 \pm 3.31$ \\
TPSBF & $58.15 \pm 1.16$ & $5.37 \pm 1.4$ & \\
\hline
\end{tabular}

provided better matrix adhesion on the fiber surface, as there were no voids at the interface between the components.

The bleached treatment promoted the removal of the surface layer of the fibers, composed of hemicellulose and lignin, leaving the cellulose more exposed. As glucose units form both cellulose and starch, there is a strong interaction between them, especially hydrogen bonds ${ }^{[37]}$.

Also, silica $\left(\mathrm{SiO}_{2}\right)$, present on the fiber surface (it was not completely removed by the treatments) can strongly interact with $\mathrm{OH}$ group from TPS ${ }^{[37]}$. Silica can interact with the unsaturated bonds of polymer molecules (TPS) through electrons of the fiber's unsaturated bonds ${ }^{[59]}$.

Figure 6 shows the XRD of TPS and composites. XDR of the thermoplastic starch (TPS) does not have the type C starches' characteristic crystallograph profile. Type C starch was observed in natural babassu starch (BS). Peaks observed a new pattern at $15.8^{\circ}$ and $24.3^{\circ}$, typical of thermoplastic starches with a crystalline V-type pattern ${ }^{[60,61]}$. As expected, and seen in Table 3, the composites' crystallinity increased according to the chemical treatment received by the fibers. The higher crystallinity was observed for the composite made with the bleached fibers.

TPS and composites TG/DTG curves (Figure 7) are very similar, virtually overlapping. The materials have lost mass relatively gradually. However, DTG curves helped identify the three most notable mass-loss events. The first ranged from $30^{\circ} \mathrm{C}$ to $130^{\circ} \mathrm{C}$ and corresponded to the loss of physisorbed water ${ }^{[62]}$. This event appears on the DSC curve (Figure 6) as an endothermic peak reaching about $180{ }^{\circ} \mathrm{C}$. The second mass loss event ranged from $140{ }^{\circ} \mathrm{C}$ to $250^{\circ} \mathrm{C}$ and mainly corresponded to the volatilization of glycerol

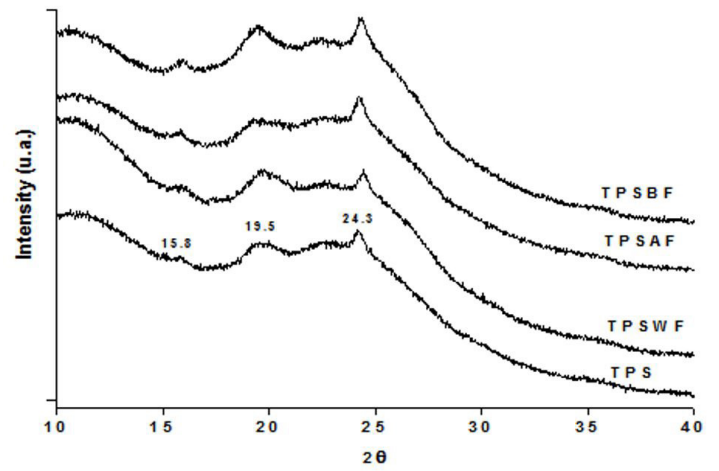

Figure 6. XRD of TPS, TPSWF, TPSAF, TPSBF.

molecules ${ }^{[37]}$. This event appears on the DSC curve as an endothermic peak. The third and most significant mass loss event ranged from $250{ }^{\circ} \mathrm{C}$ to $430{ }^{\circ} \mathrm{C}$ and corresponded to the degradation of TPS and fibers and the boiling of the remaining glycerol $\left(\mathrm{PE}=290{ }^{\circ} \mathrm{C}\right)^{[63,64]}$. This event appears on the DSC curve as an exothermic peak.

As found in nature, granular starch is a polysaccharide with polyhydroxyl groups and strong inter and intramolecular interactions of hydrogen, limiting the mobility of its molecules. It means that the starch has no melt flowability and cannot be directly processed by melting ${ }^{[65]}$. However, starch can have the granule structure destroyed if processed in the presence of a plasticizer substance (such as glycerol), under the action of heat and shear. In this material, the hydrogen bonds between the amylose and amylopectin molecules are replaced by bonds with the plasticizer molecules, causing the 
destruction of the granular crystallinity and increasing the mobility between the polymeric starch chains ${ }^{[37,60]}$. However, there is an optimum amount of plasticizer for starch, which varies with the starch's origin and makes TPS more fluid and industrially processable. Liu et al. ${ }^{[65]}$ have studied the variation of glycerol (30-50\%) added to cassava starch and found an optimum amount of glycerol that must be added to starch to make it a plasticizer. They observed that the best extrusion characteristics were achieved when $40 \%$ of glycerol was added to the starch. It is worth mentioning that we also use a $40 \%$ plasticizer (glycerol). Table 3 and Figure 8 show the results of tensile strength, elongation at break, and elastic modulus found in this work, as well as results found in the literature for comparison purposes.

The results of the TPS's mechanical properties in our study differ slightly from those found in the literature. Note that the tensile strength was more remarkable than many studies (Table 3), except for the result found by Maniglia et al. ${ }^{[29,40]}$
The mechanical behavior of matrials depends on several parameters, such as the particle distribution, dispersion, and adhesion of the matrix in the dispersed phase ${ }^{[66]}$. Plastic deformation decreases as the tensile strength and modulus increase and the elongation at break decreases.

The TPS elongation (ductility) was lower than most of the results mentioned in the literature ${ }^{[66]}$ except for the values found by Maniglia et al. and Castaño et al. ${ }^{[29,48]}$. The ductility is related to the material's softness, and the higher the value, the more ductile, the softer the material will be.

The modulus of elasticity that measures the stiffness of materials (hardness) is directly related to the forces of intermolecular and intermolecular connections. For this parameter, the results found were superior to the results shown by Campos et al. ${ }^{[37]}$, Castaño et al. ${ }^{[48]}$, and Fazeli et al. ${ }^{[67]}$.

The described composites were obtained using TPS with $40 \%$ glycerol with plasticizer and without chemical
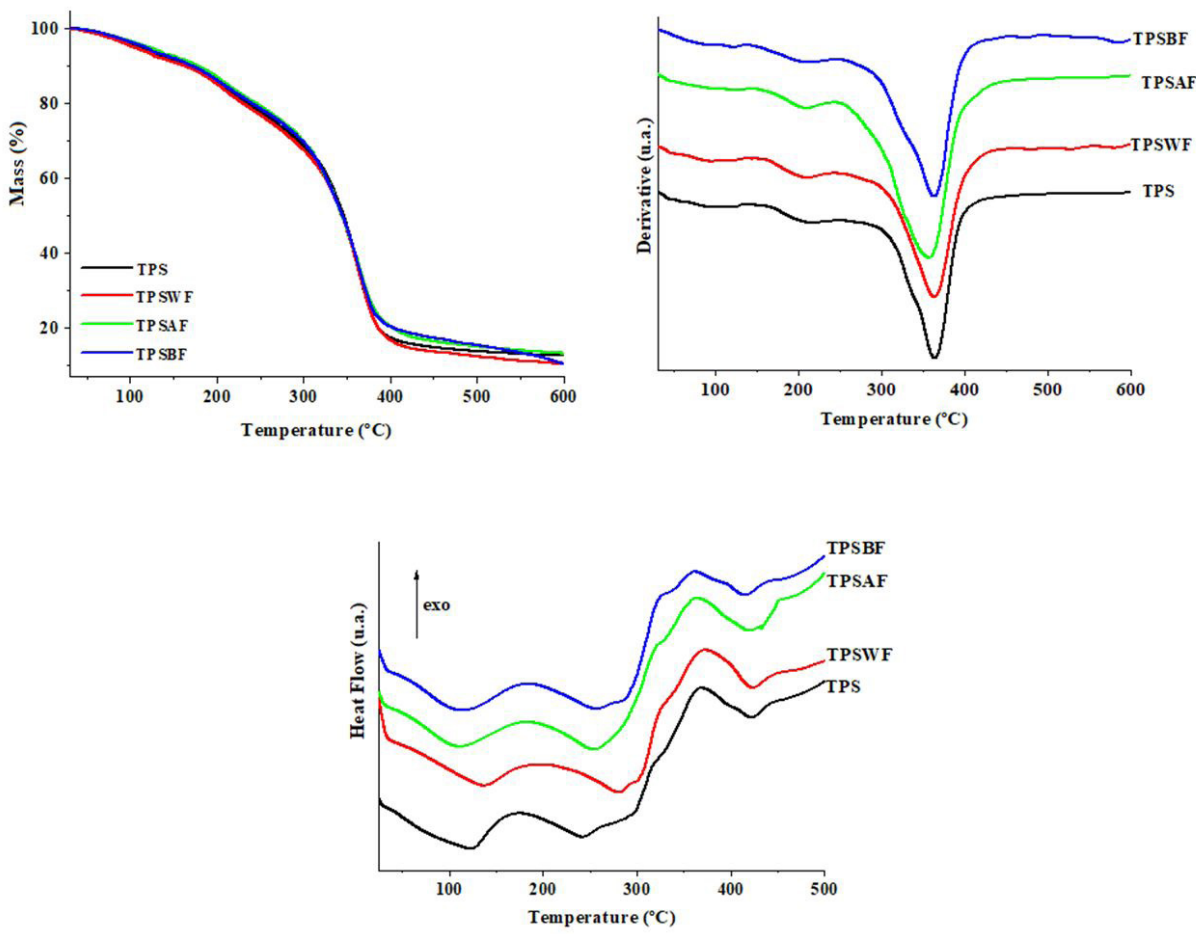

Figure 7. TG/DTG and DSC curves of TPS, TPSWF, TPSAF, and TPSBF.
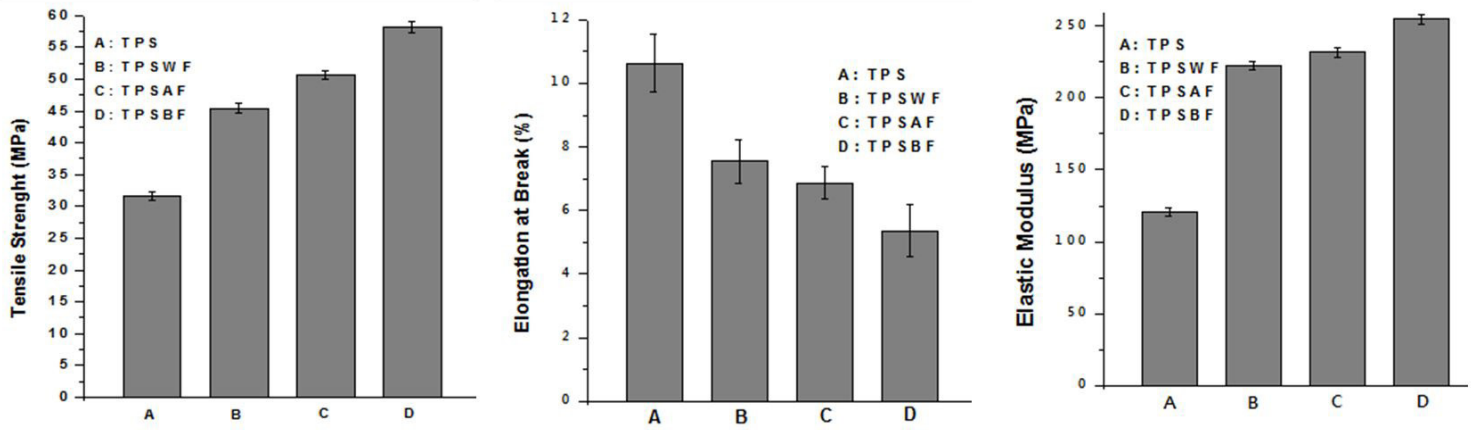

Figure 8. Mechanical Properties of TPS and Composites. 
treatment. Chemical treatment was carried out in order to eliminate waxes, lignin, and hemicellulose. Also, the fibers have a great attraction for water due to their structure, and the removal of these components from the fibers implies a more significant interaction between the fibers and the polymeric matrix, resulting in increased stress transfer, improving the mechanical properties, as well as reducing the water absorption ${ }^{[68]}$.

In general, the mechanical properties analyzed (tensile strength, modulus of elasticity, and elongation) of the composites showed improvements if compared to neat TPS

Chemical treatment with $\mathrm{NaOH}$ (mercerization) improves the mechanical properties, mainly the tensile strength and elongation. In bleaching, this treatment improves the fiber/ TPS adhesion, giving a more significant interaction between the fiber and the TPS components. This interaction occurs mainly via hydrogen bonding between the hydroxyl groups of the fibers and the TPS ${ }^{[37]}$. The removal of lignin and hemicellulose can be seen by FTIR analysis, where the band at $1742 \mathrm{~cm}^{-1}$, attributed to the stretching of the ester $\mathrm{C}=\mathrm{O}$ bond, disappeared for TPSBF composite. It appears that the band at $1249 \mathrm{~cm}^{-1}$, related to $\alpha-\mathrm{C}-\mathrm{O}-\mathrm{C}$, was reduced for the treated fibers.

The composites where the fiber was chemically treated (TPSAF, TPSBF) showed better mechanical properties than the composite made with the untreated fiber (TPSWF), showing that while hydrophilic materials were removed from the fibers, adhesion with the TPS (hydrophobic) was more effective.

The mechanical properties of composites are shown in Table 3. The tensile strength of TPSWF $(45.38 \pm 1.07 \mathrm{MPa})$, TPSAF (50.58 $\pm 1.13 \mathrm{MPa})$, and TPSBF $(58.15 \pm 1.16 \mathrm{MPa})$ are higher than the pure TPS matrix, which presented a maximum tension of $31.67 \pm 1.07 \mathrm{MPa}$. The maximum tensions were $43.3 \%, 59.7 \%$, and $83.6 \%$ higher than the pure TPS matrix, respectively. The TPSWF composite has a lower tensile strength than the other composites that may have been caused by void formations at the interface between the fibers and the TPS, resulting in a discontinuous matrix, as shown by the SEM images. The results of tensile strength presented in this work have been better than the ones described by Grylewicz et al. (5.7 MPa), that used TPS from starch potato and wood fiber in a rate $88.12 \%$, respectively ${ }^{[69]}$.

The elongation at break of the composites, TPSWF ( $7.54 \pm 1.6 \%)$, TPSAF $(6.87 \pm 1.7 \%)$, TPSBF $(5.37 \pm 1.4 \%)$, were smaller than the ones found by Campos et al. ${ }^{[37]}$, Fazelli et al. ${ }^{[67]}$, and Grylewicz et al. ${ }^{[69]}$ The results of elastic modulus found for the composites were $222.36 \pm$ $3.27 \mathrm{MPa}$ (TPSWF), $231.65 \pm 3.19 \mathrm{MPa}$ (TPSAF), and $254.81 \pm 3.31 \mathrm{MPa}$ (TPSBF). This improvement related to TPS is due to the strong interfacial interaction between the starch and the fibers ${ }^{[65,70]}$. The elasticity modulus was $84.30 \%, 91.99 \%$, and $111.19 \%$, more significant than the pure TPS, respectively. Fontelles et al. ${ }^{[68]}$ prepared composites using babassu epicarp fibers with and without chemical treatment and as a matrix using unsaturated polyester and orthopthalic resin. The results showed for the composite made with fibers without chemical treatment, $15 \mathrm{Mpa}$ for tensile strength, $1.8 \%$ for elongation, and $1600 \mathrm{MPa}$ for

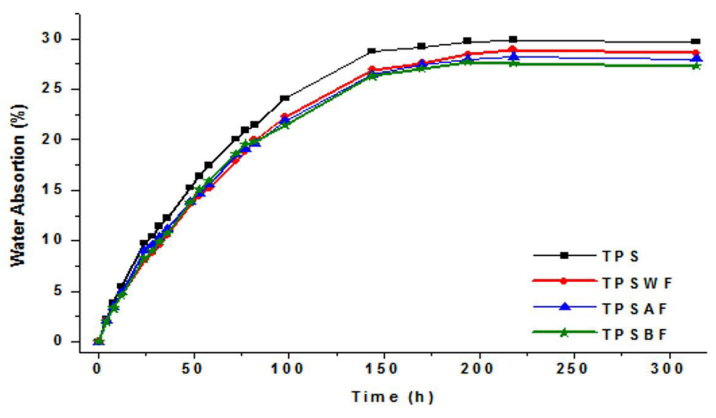

Figure 9. Water Absorption of TPS, TPSWF, TPSAF, and TPSBF.

elastic modulus, and with chemical treatment, $18 \mathrm{MPa}$, $2.2 \%$, and $1500 \mathrm{MPa}$, respectively.

When comparing the mechanical properties found for the TPSWF and TPSAF composites, it appears that they do not differ much from each other. This fact is probably due to the $\mathrm{O}-\mathrm{H}$ and $\mathrm{Si}-\mathrm{O}$ interactions between TPS and fibers. However, as the bleached fibers' changes were more pronounced, the results of the mechanical properties of this composite (TPSBF) were much better than the properties of the other composites (TPSWF and TPSAF). The results of mechanical properties found by Fontelles et al. ${ }^{[68]}$ do not differ between treated and untreated fibers. The same result was observed in our work.

The results of water absorption (75\% humidity) are shown in Figure 9. It can be seen that the largest mass gain (water) for both TPS and composites was after $194 \mathrm{~h}$. Also, it is noted that the composites had less moisture absorption than pure TPS. Theoretically, composites should have greater moisture absorption than the original matrix due to the fibers' hydrophilic character ${ }^{[68]}$. However, in this case, the matrix is thermoplastic starch, a compound also hydrophilic, with great water absorption capacity ${ }^{[23]}$. The amount of water absorbed by the TPS and the compounds gradually increased up to $150 \mathrm{~h}$. From that time on, the amount of water absorbed was small and remained practically the same until the end of the test, reaching the maximum absorption at $194 \mathrm{~h}$. The maximum water absorption $(300 \mathrm{~h})$ was $29.7 \%, 28.6 \%, 27.9 \%$ and $27.5 \%$ (TPS, TPSWF, TPSAF and TPSBF), respectively. The literature reports similar results with $25.37 \%$ TPS/Sisal fiber ${ }^{[71,72]}$, and $27.1 \%$ TPS/ Luffa fiber ${ }^{[59]}$. The TPSBF compound had the least amount of water absorption, which is $7.4 \%$ less than the amount of pure TPS absorption. The TPSWF and TPSAF composites showed a water absorption amount of $3.7 \%$ and $6.1 \%$ less than that of the pure matrix. With the addition of fibers, this problem can be alleviated. ${ }^{[73]}$. The moisture absorption results showed that the composites absorbed less water than the TPS and improved the composite properties.

\section{Conclusion}

Many studies show the use of TPS of several starches as a matrix to obtain composites with fibers. However, the use of TPS derived from babassu starch and composites reinforced with babassu fiber is being described for the first time. The textures of the babassu epicarp applied as reinforcement in composites presented thermal properties 
and X-ray diffraction patterns, like other botanical sources. The chemical treatments applied to the fibers promoted the removal of wax, hemicellulose and lignin, revealing its internal fibrillar structure. The bleaching process developed the most significant modifications, causing a reduction in moisture absorption. X-ray results showed an increase in the crystallinity of the fibers. SEM images and infrared spectra showed that compounds such as wax, lignin, and hemicellulose were removed from the fiber surface. The SEM images of the TPS starch showed a smooth and uniform surface. In the case of composites, SEM images show voids between the fiber and the TPS for the composite TPSWF (washed fiber) and better adhesion for the composites TPSAF (alkalinized fiber) and TPSBF (bleached fiber). The fiber treatments resulted in more significant interfacial interaction between the TPS and the fibers. There was a substantial improvement in the mechanical properties of the composites compared to the pure TPS, i.e., higher tensile strength and modulus of elasticity, making the composites more rigid. The mechanical properties found for the TPSWF and TPSBF composites, do not differ much from each other. However, as the bleached fibers' changes were more pronounced, the results of the mechanical properties of this composite (TPSBF) were better than the properties of the other composites (TPSWF and TPSAF).

\section{Acknowledgements}

The authors would like to thank Coordenação de Aperfeiçoamento de Pessoal de Nível Superior - CAPES and Conselho Nacional de Desenvolvimento Científico e Tecnológico - CNPQ (for their financial support).

\section{References}

1. Dominici, F., Gigli, M., Armentano, I., Genovese, L., Luzi, F., Torre, L., Munari, A., \& Lotti, N. (2020). Improving the flexibility and compostability of starch/poly(butylene cyclohexanedicarboxylate)-based blends. Carbohydrate Polymers, 246, 116631. http://dx.doi.org/10.1016/j.carbpol.2020.116631. PMid:32747266.

2. Liu, W., Wang, Z., Liu, J., Dai, B., Hu, S., Hong, R., Xie, H., Li, Z., Chen, Y., \& Zeng, G. (2020). Preparation, reinforcement and properties of thermoplastic starch film by film blowing. Food Hydrocolloids, 108, 106006. http://dx.doi.org/10.1016/j. foodhyd.2020.106006.

3. RameshKumar, S., Shaiju, P., O'Connor, K. E., \& Babu, R. (2020). Bio-based and biodegradable polymers - State-ofthe-art, challenges and emerging trends. Current Opinion in Green and Sustainable Chemistry, 21, 75-81. http://dx.doi. org/10.1016/j.cogsc.2019.12.005.

4. Stepto, R. F. T. (2006). Understanding the processing of thermoplastic starch. Macromolecular Symposia, 245-246(1), 571-577. http://dx.doi.org/10.1002/masy.200651382.

5. Khan, B., Bilal Khan Niazi, M., Samin, G., \& Jahan, Z. (2017). Thermoplastic starch: A possible biodegradable food packaging material-A review. Journal of Food Process Engineering, 40(3), 12447-12454. http://dx.doi.org/10.1111/jfpe.12447.

6. Rhim, J. W., Park, H. M., \& Ha, C. S. (2013). Bio-nanocomposites for food packaging applications. Progress in Polymer Science, 38(10-11), 1629-1652. http://dx.doi.org/10.1016/j. progpolymsci.2013.05.008.

7. Tănase, E. E., Popa, M. E., Râpă, M., \& Popa, O. (2015). PHB/cellulose fibers based materials: physical, mechanical and barrier properties. Agriculture and Agricultural Science Procedia, 6, 6. http://dx.doi.org/10.1016/j.aaspro.2015.08.099.

8. El Miri, N., Abdelouahdi, K., Barakat, A., Zahouily, M., Fihri, A., Solhy, A., \& El Achaby, M. (2015). Bio-nanocomposite films reinforced with cellulose nanocrystals: rheology of filmforming solutions, transparency, water vapor barrier and tensile properties of films. Carbohydrate Polymers, 129, 156-167. http://dx.doi.org/10.1016/j.carbpol.2015.04.051. PMid:26050901.

9. Fringant, C., Rinaudo, M., Foray, M. F., \& Bardet, M. (1998). Preparation of mixed esters of starch or use of an external plasticizer: two different ways to change the properties of starch acetate films. Carbohydrate Polymers, 35(1-2), 97-106. http://dx.doi.org/10.1016/S0144-8617(97)00250-6.

10. Liu, W., Liu, S., Wang, Z., Dai, B., Liu, J., Chen, Y., Zeng, G., He, Y., Liu, Y., \& Liu, R. (2019). Preparation and characterization of reinforced starch-based composites with compatibilizer by simple extrusion. Carbohydrate Polymers, 223, 115122. http:// dx.doi.org/10.1016/j.carbpol.2019.115122. PMid:31426949.

11. Omotoso, M. A., Adeyefa, O. S., Animashaum, E. A., \& Osibanjo, O. O. (2015). Biogradable Starch Film from Cassava, Corn, Potato and Yam. Chemistry and Materials Research, 7(12), 15-24.

12. Jullanun, P., \& Yoksan, R. (2020). Morphological characteristics and properties of TPS/PLA/cassava pulp biocomposites. Polymer Testing, 88, 106522. http://dx.doi.org/10.1016/j. polymertesting.2020.106522.

13. Florez, J. P., Fazeli, M., \& Simão, R. A. (2019). Preparation and characterization of thermoplastic starch composite reinforced by plasma-treated poly (hydroxybutyrate) PHB. International Journal of Biological Macromolecules, 123, 609-621. http:// dx.doi.org/10.1016/j.ijbiomac.2018.11.070. PMid:30447362.

14. Nagarajan, V., Misra, M., \& Mohanty, A. K. (2013). New engineered biocomposites from poly (3-hydroxybutyrateco-3-hydroxyvalerate)(PHBV)/poly (butylene adipate-coterephthalate)(PBAT) blends and switchgrass: fabrication and performance evaluation. Industrial Crops and Products, 42, 461-468. http://dx.doi.org/10.1016/j.indcrop.2012.05.042.

15. Wang, Y., Weng, Y., \& Wang, L. (2014). Characterization of interfacial compatibility of polylactic acid and bamboo flour (PLA/BF) in biocomposites. Polymer Testing, 36, 119-125. http://dx.doi.org/10.1016/j.polymertesting.2014.04.001.

16. Muthuraj, R., Misra, M., Defersha, F., \& Mohanty, A. K. (2016). Influence of processing parameters on the impact strength of biocomposites: a statistical approach. Composites. Part A, Applied Science and Manufacturing, 83, 120-129. http:// dx.doi.org/10.1016/j.compositesa.2015.09.003.

17. Wan, Y. Z., Luo, H., He, F., Liang, H., Huang, Y., \& Li, X. L. (2009). Mechanical, moisture absorption, and biodegradation behaviours of bacterial cellulose fiber-reinforced starch biocomposites. Composites Science and Technology, 69(7-8), 1212-1217. http://dx.doi.org/10.1016/j.compscitech.2009.02.024.

18. Khan, B., Niazi, M. B. K., Samin, G., \& Jahan, Z. (2017). Thermoplastic starch: A possible biodegradable food packaging material-A review. Journal of Food Process Engineering, 40(3), 12447-12454. http://dx.doi.org/10.1111/jfpe.12447.

19. Ashori, A. (2008). Wood-plastic composites as promising green-composites for automotive industries! Bioresource Technology, 99(11), 4661-4667. http://dx.doi.org/10.1016/j. biortech.2007.09.043.

20. Pickering, K., Aruan Efendy, M., \& Le, T. (2016). A review of recent developments in natural fibre composites and their mechanical performance. Composites. Part A, Applied Science and Manufacturing, 83, 98-112. http://dx.doi.org/10.1016/j. compositesa.2015.08.038. 
21. Zaman, H. U., Khan, M. A., \& Khan, R. A. (2011). A comparative study on the mechanical and degradation properties of plant fiber reinforced polyethylene composites. Polymer Composites, 32(10), 1552-1560. http://dx.doi.org/10.1002/pc.21168.

22. Shoja, M., Mohammadi-Roshandeh, J., Hemmati, F., Zandi, A., \& Farizeh, T. (2020). Plasticized starch-based biocomposites containing modified rice straw fillers with thermoplastic, thermoset-like and thermoset chemical structures. International Journal of Biological Macromolecules, 157, 715-725. http:// dx.doi.org/10.1016/j.ijbiomac.2019.11.236. PMid:31794825.

23. Vedove, T. M. A. R. D., Maniglia, B. C., \& Tadini, C. C. (2021). Production of sustainable smart packaging based on cassava starch and anthocyanin by an extrusion process. Journal of Food Engineering, 289, 110274. http://dx.doi.org/10.1016/j. jfoodeng.2020.110274.

24. Zhou, X., Cheng, R., Wang, B., Zeng, J., Xu, J., Li, J., Kang, L., Cheng, Z., Gao, W., \& Chen, K. (2021). Biodegradable sandwich-architectured films derived from pea starch and polylactic acid with enhanced shelf-life for fruit preservation. Carbohydrate Polymers, 251,117117. http://dx.doi.org/10.1016/j. carbpol.2020.117117. PMid:33142652.

25. Palanisamy, C. P., Cui, B., Zhang, H., Jayaraman, S., \& Kodiveri Muthukaliannan, G. (2020). A comprehensive review on corn starch-based nanomaterials: properties, simulations, and applications. Polymers, 12(9), 2161. http://dx.doi.org/10.3390/ polym12092161. PMid:32971849.

26. Mayandi, K., Rajini, N., Pitchipoo, P., Sreenivasan, V. S., Winowlin Jappes, J. T., \& Alavudeen, A. (2015). A comparative study on characterisations of Cissus quadrangularis and Phoenix reclinata natural fibers. Journal of Reinforced Plastics and Composites, 34(4), 269-280. http://dx.doi.org/10.1177/0731684415570045.

27. Zainuddin, S. Y. Z., Ahmad, I., Kargarzadeh, H., Abdullah, I., \& Dufresne, A. (2013). Potential of using multiscale kenaf fibers as reinforcing filler in cassava starch-kenaf biocomposites. Carbohydrate Polymers, 92(2), 2299-2305. http://dx.doi. org/10.1016/j.carbpol.2012.11.106. PMid:23399291.

28. Perez, C. M., \& Juliano, B. O. (1978). Modification of the simplified amylose test for milled rice. Starch. Biosythesis Nutrition Biomedical, 30(12), 424-426. http://dx.doi.org/10.1002/ star.19780301206.

29. Maniglia, B. C., Tessaro, L., Ramos, A. P., \& Tapia-Blácido, D. R. (2019). Which plasticizer is suitable for films based on babassu starch isolated by different methods? Food Hydrocolloids, 89, 143-152. http://dx.doi.org/10.1016/j.foodhyd.2018.10.038.

30. Ferreira, D. C. M., Molina, G., \& Pelissari, F. M. (2020). Effect of edible coating from cassava starch and babassu flour (Orbignya phalerata) on Brazilian Cerrado Fruits Quality. Food and Bioprocess Technology, 13(1), 172-179. http://dx.doi. org/10.1007/s11947-019-02366-z.

31. Vieira, A. P., Santana, S. A. A., Bezerra, C. W. B., Silva, H. A. S., Chaves, J. A. P., Melo, J. C. P., Silva Filho, E., \& Airoldi, C. (2011). Epicarp and Mesocarp of Babassu (Orbignya speciosa): Characterization and Application in Copper Phtalocyanine Dye Removal. Journal of the Brazilian Chemical Society, 22(1), 21-29. http://dx.doi.org/10.1590/S0103-50532011000100003.

32. Furtado, J. B. M., Furtado Filho, P. A., Oliveira, T. P., Caetano, M. R. S., Araújo, I. M. S., Figueiredo, F. C., \& Santos, J. R. Jr. (2020). Chemical caracterization of the fiber of the stem of the babaçu palm tree natural and after treatment. Revista de Engenharia e Pesquisa Aplicada, 5(3), 56-64. http://dx.doi. org/10.25286/repa.v5i3.1254.

33. Abidi, N., Cabrales, L., \& Haigler, C. H. (2014). Changes in the cell wall and cellulose content of developing cotton fibers investigated by FTIR spectroscopy. Carbohydrate Polymers, 100, 9-16. http://dx.doi.org/10.1016/j.carbpol.2013.01.074. PMid:24188832.
34. Santos, E. B. C., Moreno, C. G., Barros, J. J. P., Moura, D. A., Fim, F. C., Ries, A., Wellen, R. M. R., \& Silva, L. B. (2018). Effect of Alkaline and Hot water treatments on the structure and morphology of piassava fibers. Materials Research, 21(2), e20170365. http://dx.doi.org/10.1590/1980-5373-mr-2017-0365.

35. Morales-Cepeda, A. B., Ponce-Medina, M. E., SalasPapayanopolos, H., Lozano, T., Zamudio, M., \& Lafleur, P. G. (2015). Preparation and characterization of candelilla fiber (Euphorbia antisyphilitica) and its reinforcing effect in polypropylene composites. Cellulose (London, England), 22(6), 3839-3849. http://dx.doi.org/10.1007/s10570-015-0776-y.

36. Zhang, T., Guo, M., Cheng, L., \& Li, X. (2015). Investigations on the structure and properties of palm leaf sheath fiber. Cellulose (London, England), 22(2), 1039-1051. http://dx.doi. org/10.1007/s10570-015-0570-x.

37. Campos, A., Sena Neto, A. R., Rodrigues, V. B., Luchesi, B. R., Mattoso, L. H. C., \& Marconcini, J. M. (2018). Efeect of raw and chemically treated oil palm mesocarp fibers on thermoplastic cassava starch properties. Industrial Crops and Products, 124, 149-154. http://dx.doi.org/10.1016/j.indcrop.2018.07.075.

38. Valcárcel-Yamani, B., Rondán-Sanabria, G. G., \& FinardiFilho, F. (2013). The physical, chemical and functional characterization of starches from Andean tubers: Oca (Oxalis tuberosa Molina), olluco (Ullucus tuberosus Caldas) and mashua (Tropaeolum tuberosum Ruiz \& Pavón). Brazilian Journal of Pharmaceutical Sciences, 49(3), 453-464. http:// dx.doi.org/10.1590/S1984-82502013000300007.

39. Jimenéz-Hernández, J., Salazar-Montoya, J. A., \& RamosRamírez, E. G. (2007). Physical, chemical and microscopic characterization of a new starch from chayote (Sechium edule) tuber and its comparison with potato and maize starches. Carbohydrate Polymers, 68(4), 679-686. http://dx.doi. org/10.1016/j.carbpol.2006.07.035.

40. Maniglia, B. C., \& Tapia-Blácido, D. R. (2016). Isolation and characterization of starch from Babassu mesocarp. Food Hydrocolloids, 55, 47-55. http://dx.doi.org/10.1016/j. foodhyd.2015.11.001.

41. Zimmermann, M. V. G., Turella, T. C., Zattera, A. J., \& Santana, R. M. C. (2014). Influence of the chemical treatment of banana fiber on poly(ethylene-co-vinyl acetate) composites with and without a blowing agent. Polímeros: Ciencia e Tecnologia, 24(1), 58-64. http://dx.doi.org/10.4322/polimeros.2013.071.

42. Kabir, M. M., Wang, H., Lau, K. T., \& Cardona, F. (2013). Effects of chemical treatments on hemp fiber structure. Applied Surface Science, 276, 13-23. http://dx.doi.org/10.1016/j. apsusc.2013.02.086.

43. Martin, A., Martins, M. A., Mattoso, L. H. C., \& Silva, O. R. R. F. (2009). Chemical and Structural Characterization of Sisal Fibers from Agave sisalana Variety. Polímeros: Ciência e Tecnologia, 19(1), 40-46. http://dx.doi.org/10.1590/S010414282009000100011.

44. Porras, A., Maranon, A., \& Ashcroft, I. A. (2015). Characterization of a novel natural cellulose fabric from Manicaria saccifera palm as possible reinforcement of composite materials. Composites. Part B, Engineering, 74(1), 66-73. http://dx.doi. org/10.1016/j.compositesb.2014.12.033.

45. Barreto, A. C. H., Rosa, D. S., Fechine, P. B. A., \& Mazzetto, S. E. (2011). Properties of sisal fibers treated by alkali solution and their application into cardanol-based biocomposites. Composites. Part A, Applied Science and Manufacturing, 42(5), 492-500. http://dx.doi.org/10.1016/j.compositesa.2011.01.008.

46. Gonçalves, A. P. B., Miranda, C. S., Guimarães, D. H., Oliveira, J. C., Cruz, A. M. F., Silva, F. L. B. M., Luporini, S., \& José, N. M. (2015). Physicochemical, mechanical and morphologic characterization of purple banana fibers. Materials Research, 
18(2, Suppl. 2), 205-209. http://dx.doi.org/10.1590/15161439.366414.

47. Sajilata, M. G., Singhal, R. S., \& Kulkarni, P. R. (2006). Resistant starch-A Review. Comprehensive Reviews in Food Science and Food Safety, 5(1), 1-17. http://dx.doi. org/10.1111/j.1541-4337.2006.tb00076.x. PMid:33412740.

48. Castaño, J., Rodriguez-Llamazares, S., Contreras, K., Carrasco, C., Pozo, C., Bouza, R., Franco, C. M. L., \& Giraldo, D. (2014). Horse chestnut (Aesculus hippocastanum L.) starch: basic physico-chemical characteristics and use as thermoplastic material. Carbohydrate Polymers, 112, 677-685. http://dx.doi. org/10.1016/j.carbpol.2014.06.046. PMid:25129797.

49. Qin, F., Man, J., Cai, C., Xu, B., Gu, M., Zhu, L., Shi, Y. C., Liu, Q., \& Wei, C. (2012). Physicochemical properties of high-amylose rice starches during kernel development. Carbohydrate Polymers, 88(2), 690-698. http://dx.doi. org/10.1016/j.carbpol.2012.01.013.

50. Copeland, L., Blazek, J., Salman, H., \& Tang, M. C. (2009). Form and functionality of starch. Food Hydrocolloids, 23(6), 1527-1534. http://dx.doi.org/10.1016/j.foodhyd.2008.09.016.

51. Pelissari, F. M., Andrade-Mahecha, M. M., Sobral, P. J. D. A., \& Menegalli, F. C. (2012). Isolation and characterization of the flour and starch of plantain bananas (Musa paradisiaca). Starch: Biosynthesis Nutrition Biomedical, 64(5), 382-391. http://dx.doi.org/10.1002/star.201100133.

52. Guimarães, J. L., Frollini, E., Silva, C. G., Wypych, F., \& Satyanarayana, K. G. (2009). Characterization of banana, sugarcane bagasse and sponge gourd fibers of Brazil. Industrial Crops and Products, 30(3), 407-415. http://dx.doi.org/10.1016/j. indcrop.2009.07.013.

53. Sheltami, R. M., Abdullah, I., Ahmad, I., Dufresne, A., \& Kargarzadeh, H. (2012). Extraction of cellulose nanocrystals from mengkuang leaves (Pandanus tectorius). Carbohydrate Polymers, 88(2), 772-779. http://dx.doi.org/10.1016/j.carbpol.2012.01.062.

54. Collazo-Bigliardi, S., Ortega-Toro, R., \& Chiralt Boix, A. (2018). Isolation and characterisation of microcrystalline cellulose and celulose nanocrystals from coffee husk and comparative study with rice husk. Carbohydrate Polymers, 191, 205-215. http:// dx.doi.org/10.1016/j.carbpol.2018.03.022. PMid:29661311.

55. Teixeira, P. R. S., Teixeira, A. S. N. M., Farias, E. A. O., Silva, D. A., Nunes, L. C. C., Leite, C. M. S., Silva Filho, E. C., \& Eiras, C. (2018). Chemically modified Babassu coconut (Orbignya sp.) biopolymer: characterization and development of a thin film for its application in electrochemical sensors. Journal of Polymer Research, 25(127), 1-11. http://dx.doi. org/10.1007/s10965-018-1520-8.

56. Bhaduri, S. K., Mathew, M. D., Day, A., \& Pandey, S. N. (1994). Thermal behaviour of jute fiber and its components. I: D.S.C. studies. Cellulose Chemistry and Technology, 28(4), 391-399. http://dx.doi.org/10.1177/004051759306300303.

57. Shafizadeh, F., \& Bradbury, A. G. W. (1979). Thermal degradation of cellulose in air and nitrogen at low temperatures. Journal of Applied Polymer Science, 23(5), 1431-1442. http://dx.doi. org/10.1002/app.1979.070230513.

58. Kaewtatip, K., \& Thongmee, J. (2014). Preparation of thermoplastic starch/treated bagasse fiber composites. Starch: Biosynthesis Nutrition Biomedical, 66(7-8), 724-728. http:// dx.doi.org/10.1002/star.201400005.

59. Kaewtatip, K., \& Thongmee, J. (2013). Effect of kraft lignin and esterified lignin on the properties of thermoplastic starch. Materials \& Design, 49, 701-704. http://dx.doi.org/10.1016/j. matdes.2013.02.010.

60. Wang, Z., Gu, Z., Hong, Y., Cheng, L., \& Li, Z. (2011). Bonding strength and water resistance of starchbased wood adhesive improved by silica nanoparticles. Carbohydrate Polymers, 86(1), 72-76. http://dx.doi.org/10.1016/j.carbpol.2011.04.003.
61. Corradinia, E., Carvalho, A. J. F., Curvelo, A. A. S., Agnellia, J. A. M., \& Mattoso, L. H. C. (2007). Preparation and characterization of Thermoplastic Starch/Zein Blends. Materials Research, 10(3), 227-231. http://dx.doi.org/10.1590/S151614392007000300002.

62. Mendes, J. F., Paschoalin, R. T., Carmona, V. B., Sena Neto, A. R., Marques, A. C. P., Marconcini, J. M., Mattoso, L. H. C., Medeiros, E. S., \& Oliveira, J. E. (2016). Biodegradable polymer blends based on corn starch and thermoplastic chitosan processed by extrusion. Carbohydrate Polymers, 137, 452-458. http://dx.doi.org/10.1016/j.carbpol.2015.10.093. PMid:26686150.

63. Prachayawarakorn, J., Chaiwatyothin, S., Mueangta, S., \& Hanchana, A. (2013). Effect of jute and kapok fibers on properties of thermoplastic cassava starch composites. Materials \& Design, 47, 309-315. http://dx.doi.org/10.1016/j. matdes.2012.12.012.

64. Ibrahim, H., Farag, M., Megahed, H., \& Mehanny, S. (2014). Characteristics of starch-based biodegradable composites reinforced with date palm and flax fibers. Carbohydrate Polymers, 101, 11-19. http://dx.doi.org/10.1016/j.carbpol.2013.08.051. PMid:24299743.

65. Liu, H., Xie, F., Yu, L., Chen, L., \& Li, L. (2009). Thermal processing of starch-based polymers. Progress in Polymer Science, 34(12), 1348-1368. http://dx.doi.org/10.1016/j. progpolymsci.2009.07.001.

66. Vasconcelos, G. C. M. S., Carvalho, L. H., Barbosa, R., \& Alves, T. (2019). Evaluation of the morphology, mechanical and thermal properties of cork and green polyethylene ecocomposites. Materials Research Express, 6(095331), 1-11. http://dx.doi.org/10.1088/2053-1591/ab33b8.

67. Fazeli, M., Florez, J. P., \& Simão, R. A. (2019). Improvement in adhesion of cellulose fibers to the thermoplastic starch matrix by plasma treatment modification. Composites. Part B, Engineering, 163(15), 207-216. http://dx.doi.org/10.1016/j. compositesb.2018.11.048.

68. Fonteles, C. A. L., Brito, G. F., Carvlho, L. H., Alves, T. S., \& Barbosa, R. (2016). Composites based on thermoset resin and Orbignya phalerata (Babassu Coconut): Evaluation of mechanical properties, morphology and water sorption. Materials Science Forum, 869, 237-242, 242. http://dx.doi. org/10.4028/www.scientific.net/MSF.869.237<jrn>

69. Grylewicz, A., Spychaj, T., \& Zdanowicz, M. (2019). Thermoplastic starch/wood biocomposites processed with deep eutectic solvents. Composites. Part A, Applied Science and Manufacturing, 121, 517-524. http://dx.doi.org/10.1016/j. compositesa.2019.04.001.

70. Zhang, Y., Rempel, C., \& Liu, Q. (2014). Thermoplastic starch processing and characteristics - A Review. Critical Reviews in Food Science and Nutrition, 54(10), 1353-1370. http://dx.doi. org/10.1080/10408398.2011.636156. PMid:24564592.

71. Corradini, E., Agnelli, J. A. M., Morais, L. C., \& Mattoso, L. H. C. (2008). Study of properties of biodegradable composites of starch/gluten/glycerol reinforced with sisal fibers. Polimeros: Ciência e Tecnologia, 18(4), 353-358. http://dx.doi.org/10.1590/ S0104-14282008000400016.

72. Xie, Q., Li, F., Li, J., Wang, L., Li, Y., Zhang, C., Xu, J., $\&$ Chen, S. (2018). A new biodegradable sisal fiber-starch packing composite with nest structure. Carbohydrate Polymers, 189(1), 56-64. http://dx.doi.org/10.1016/j.carbpol.2018.01.063. PMid:29580426.

Reveived: Feb. 10, 2020

Revised: Jan. 29, 2021

Accepted: Feb. 24, 2021 